\title{
BIOSINTESIS NANOPARTIKEL PERAK MENGGUNAKAN EKSTRAK BUAH Passiflora flavicarva (MARKISA) UNTUK MENDETEKSI LOGAM BERAT
}

\author{
Dina Maryani ${ }^{* 1}$, M. Lutfi Firdaus ${ }^{2}$, Nurhamidah ${ }^{3}$ \\ Program Studi Pendidikan Kimia Fakultas Keguruan dan Ilmu Pendidikan Universitas Bengkulu \\ ${ }^{1,2,3}$ Program Studi Pendidikan Kimia, Jurusan PMIPA, FKIP, Universitas Bengkulu \\ *11e-mail : dinamaryani383@gmail.com
}

\begin{abstract}
The aim of this research was to synthesize silver nanoparticle (NPP) by using Passiflora flavicarva (Markisa) fruit extract as detector of heavy metal. The NPP particles produced were determined by their optimum condition on the ratio of the volume of Passiflora flavicarva passion fruit extract to $\mathrm{AgNO}_{3}$ and the reaction time. The silver nanoparticles produced under optimum conditions will be tested for selectivity against several metals that are often present in the environment, once the selective metal is known then it can be sensitized to the metal using a UV-Vis spectrophotometer to determine the minimal concentrations that can be detected by the silver nanoparticles Formed. The results showed that Passiflora flavicarva passion fruit extracts could be used for the biosynthesis of NPP particles because they contain vitamin C and flavonoids capable of reducing Ag+ to Ag0 in the form of NPP. The optimal conditions for forming NPP particles are in the 1: 2 ratio with a 2 hour reaction time. From the results of selectivity test of NPP to some heavy metals that often exist in environment, it is known that NPP selective to mercury metal. It was found that selective mercury was followed by a sensitivity test with a UV-Vis spectrophotometer, with sensitive NPP up to a concentration of $6.7 \mathrm{ppm}$. From the results of this study it can be concluded that NPP particles formed can be used to detect mercury metal up to a minimum concentration of $6.7 \mathrm{ppm}$.
\end{abstract}

Keywords : Silver Nanoparticle, Passiflora flavicarva, Heavy Metal

\begin{abstract}
Abstrak
Penelitian ini bertujuan untuk melakukan sintesis nanopartikel perak (NPP) dari ekstrak buah Passiflora flavicarva (markisa) untuk mendeteksi logam berat. NPP yang dihasilkan ditentukan kondisi optimumnya pada perbandingan volume ekstrak buah $P$. flavicarva dengan $\mathrm{AgNO}_{3}$ dan waktu reaksinya.NPP yang dihasilkan dalam kondisi optimumlah yang akan diuji selektivitasnya terhadap beberapa logam yang sering terdapat di lingkungan, setelah diketahui logam yang selektif maka selanjutnya dapat dilakukan sensitifitas terhadap logam tersebut dengan menggunakan spektrofotometer UV-Vis untuk mengetahui konsentrasi minimal yang dapat dideteksi oleh NPP yang terbentuk. Hasil penelitian menunjukkan ekstrak buah $P$. flavicarva dapat digunakan untuk biosintesis NPP karena mengandung vitamin $\mathrm{C}$ dan flavonoid yang mampu mereduksi $\mathrm{Ag}^{+}$ menjadi $\mathrm{Ag}^{0}$ dalam bentuk NPP. Kondisi optimal untuk membentuk NPP berada pada perbandingan 1:2 dengan waktu reaksi 2 jam. Dari hasil uji selektivitas NPP terhadap beberapa logam berat yang sering terdapat di lingkungan, maka diketahui bahwa NPP selektif terhadap logam merkuri. Setelah diketahui bahwa logam merkuri yang selektif maka dilanjutkan dengan uji sensitivita dengan spektrofotometer UV-Vis, dengan hasil NPP sensitif sampai dengan konsentrasi 6,7 ppm. Dari hasil penelitian ini maka dapat disimpulkan bahwa NPP yang terbentuk dapat digunakan untuk mendeteksi logam merkuri sampai dengan konsentrasi
\end{abstract} minimal 6,7 ppm.

Kata kunci: Nanopartikel perak, Passiflora flavicarva, Logam berat

\section{PENDAHULUAN}

Peningkatan jumlah penduduk akan menambah aktivitas dan tidak dapat dihindari akan diikuti dengan penambahan limbah cair, padat maupun gasm salah satunya berupa limbah logam berat [1] akibat dari banyaknya industri yang menggunakan logam berat sebagai bahan baku atau bahan tambahan [2].

Adanya logam berat pada perairan dapat menjadi masalah yang serius karena berbahaya terhadap kesehatan manusia, karena memiliki sifat yang tahan terhadap materi pengurai, sehingga dapat terakumulasi di dalam perairan sebagai pencemar yang berbahaya bagi makhluk hidup [3]. Metode yang biasa digunakan untuk menganalisis atau mendeteksi logam berat pada perairan adalah Atomic Absorbtion Spectrometry
(AAS) dan Inductively Couple Plasma (ICP), yang membutuhkan waktu cukup lama dan biaya yang mahal [4].

Terkait dengan hal itu, dewasa ini telah berkembang teknologi nanopartikel atau nanoteknologi [5] yaitu suatu bahan yang memiliki ukuran 1-100 $\mathrm{nm}$ [6], dan dapat digunakan sebagai detektor atau pendektesian [7] antara lain juga dapat digunakan untuk mendeteksi logam berat.

Dewasa ini nanopartikel banyak dibuat dengan metode kimia (reduksi kimia) karena proses pembuatannya lebih mudah bisa diproduksi dalam skala besar namun menghasilkan limbah yang berbahaya serta konsumsi energi tinggi sehingga mendorong dikembangkannya metode pembuatan nanopartikel yang ramah lingkungan [8], antara lain metode biosintesis 
yang menggunakan ekstrak tumbuhan sebagai agen pereduksi [9]. Pembuatan nanopartikel dengan metode biosintesis ini melibatkan senyawa Antioksidan seperti Flavonoid dan Vitamin $\mathrm{C}$, yang dapat mereduksi $\mathrm{Ag}^{+}$ menjadi $\mathrm{Ag}^{0}$ dalam bentuk NPP [10]. Vitamin $\mathrm{C}$ memiliki nilai potensial reduksi $+0,35$ dan flavonoid memiliki potensial reduksi $+0,33$, ini lebih kecil dari potensial reduksi dari $\mathrm{Ag}+$ yaitu sebesar $+0,80$, oleh karena itu vitamin $\mathrm{C}$ dan flavonoid mampu meredusi ion Ag+ menjadi Ag0 dalam bentuk NPP. Pada penelitian ini digunakan ekstrak buah Passiflora flavicarva (markisa) sebagai agen pereduksi NPP , karena diketahui buah $P$. flavicarva memiliki kandungan vitamin $\mathrm{C}$ dan flavanoid yang cukup tinggi, yaitu 20-80 mg vitamin $\mathrm{C}$ dan 1,060 \% flavonoid per $100 \mathrm{~g}$ buah [11].

Dalam biosintesis nanopartikel terdapat beberapa metode untuk mengontrol pembentukan NPP salah satunya yaitu menggunakan sinar matahari langsung sebagai stimulus eksternal dalam proses partumbuhan NPP. Biosintesis nanopartikel logam menggunakan metode pemanasan sinar matahari memberikan kemajuan lebih besar pada kimia dan metode fisika, karena energi matahari merupakan sumber energi yang selalu tersedia, hemat biaya dan ramah lingkungan karena tidak menimbulkan polusi pada lingkungan. [12] Keberadaan sinar matahari memiliki pengaruh yang sangat kuat untuk mengontrol proses pembentukan NPP yang akan meningkat seiring bertambahnya waktu kontak dengan sinar matahari, dimana terbukti bahwa nanopartikel dari ekstrak buah pepaya terbentuk hanya dalam waktu 15 menit dengan bantuan sinar matahari [13]

Pada penelitian ini akan ditentukan selektivitas dari NPP yang terbentuk terhadap beberapa logam yang sering terdapat di lingkungan perairan, yaitu logam Al, Ca, Co, Cr, Cu, Fe, Hg, K, Mg, Mn, Na, Ni, $\mathrm{Pb}$ dan $\mathrm{Zn}$. Dari uji selektifitas ini maka bisa diketahui logam yang dapat dideteksi menggunakan nanopartikel perak yang terbentuk, selanjutnya dilakukan juga uji sensitivitas terhadap logam yang selektif tersebut dengan menggunakan metode spektrofotometer UVVis dengan berbagai variasi konsentrasi.

Berdasarkan latar belakang di atas maka penelitian "Biosintesis NPP Menggunakan Ekstrak Buah Passiflora flavicarva Untuk Mendeteksi Logam Berat" perlu dilakukan.

\section{METODE PENELITIAN}

Penelitian ini dilaksanakan pada bulan Januari 2017 - April 2017 di Laboratorium Program Studi Pendidikan Kimia, Fakultas Keguruan dan Ilmu Pendidikan Universitas Bengkulu dan Laboratorium Agronomi Universitas Bengkulu (UNIB).
Alat yang digunakan pada penelitian ini adalah: Nikon p530 500x zoom, Mini Studio, Biospektrosmeter Eppendor, Neraca Analitik, Hotplate, Gelas Kimia, Labu Ukur, Gelas Ukur, Erlenmeyer, Botol Vial, Kaca Arloji, Botol Semprot, Corong Kaca, Pipet Volumetri, Pipet Mikro, Kuvet, Sudip, Batang Pengaduk, Alumunium Foil, Cutter, Penyaring Vakum dan Derigen.

Bahan yang digunakan pada penelitian ini adalah : $\mathrm{AgNO}_{3}$, buah markisa, air demineral, aquades, $\mathrm{Al}\left(\mathrm{NO}_{3}\right)_{3} \cdot 9 \mathrm{H}_{2} \mathrm{O}, \quad \mathrm{CaCl}_{2}, \quad \mathrm{FeCl}_{2} \cdot 4 \mathrm{H}_{2} \mathrm{O}, \quad \mathrm{FeCl}_{3} \cdot 6 \mathrm{H}_{2} \mathrm{O}$, $\mathrm{CO}\left(\mathrm{NO}_{3}\right)_{2} \cdot 6 \mathrm{H}_{2} \mathrm{O}, \quad \mathrm{Cr}\left(\mathrm{NO}_{3}\right)_{3} \cdot \mathrm{H}_{2} \mathrm{O}, \quad \mathrm{Cr}\left(\mathrm{NO}_{3}\right)_{3} \cdot 9 \mathrm{H}_{2} \mathrm{O}$, $\mathrm{CuSO}_{4} \cdot 5 \mathrm{H}_{2} \mathrm{O}, \mathrm{HgCl}_{2}, \mathrm{KCl}, \mathrm{MgCl}_{2} \cdot 6 \mathrm{H}_{2} \mathrm{O}, \mathrm{MnSO}_{4} \cdot \mathrm{H}_{2} \mathrm{O}$, $\mathrm{NaCl}, \mathrm{NiSO}_{4} \cdot 6 \mathrm{H}_{2} \mathrm{O}, \mathrm{PbNO}_{3}, \mathrm{ZnCl}_{2}, \mathrm{HCl}, \mathrm{NaOH}$, air sungai hitam, air kran dekanat FKIP dan detergen.

Ekstrak buah $P$. flavicarva yang akan digunakan dibuat dengan cara membelah buah tersebut, selanjutnya diambil isinya dan ditimbang sebanyak 20 gram berat basah dan dimasukkan ke dalam gelas kimia. Pada gelas kimia ditambahkan air demineral hingga volume $100 \mathrm{~mL}$, direbus pada suhu $80^{\circ} \mathrm{C}$ selama 15 menit, kemudian didinginkan hingga mencapai suhu ruang, selanjutnya disaring menggunakan kertas saring. Filtrat rebusan buah $P$. flavicarva tersebut disimpan pada suhu $4^{0} \mathrm{C}$. Ekstrak ini dapat digunakan untuk proses biosintesis selanjutnya .

Larutan yang digunakan sebagai prekursor adalah $\mathrm{AgNO}_{3}$. Larutan baku $\mathrm{AgNO}_{3}$ dibuat dengan menimbang $0,085 \mathrm{~g} \mathrm{AgNO}_{3}$ kemudian dimasukkan ke dalam gelas kimia dan dilarutkan dengan $25 \mathrm{~mL}$ air demineral, Selanjutnya larutan $\mathrm{AgNO}_{3}$ dimasukkan ke dalam labu ukur $500 \mathrm{~mL}$ dan ditambahkan air demineral hingga tanda batas kemudian dikocok sampai homogen. Larutan perak nitrat dapat digunakan langsung untuk pembuatan NPP.

Biointesis nanopartikel perak dilakukan dengan mencampur larutan $\mathrm{AgNO}_{3} 1 \mathrm{mM}$ dan ekstrak buah markisa dengan perbandingan seperti pada Tabel .1.

Tabel 1. Perbandingan volume Filtrat dengan larutan $\mathrm{AgNO}_{3}$

\begin{tabular}{ccc}
\hline Perbandingan & $\begin{array}{c}\text { Volume Filtrat } \\
(\mathrm{mL})\end{array}$ & $\begin{array}{c}\mathrm{AgNO}_{3} 1 \mathrm{mM} \\
(\mathrm{mL})\end{array}$ \\
\hline $2: 1$ & 20 & 10 \\
$1: 1$ & 15 & 15 \\
$1: 2$ & 10 & 20 \\
$1: 3$ & 10 & 30 \\
\hline
\end{tabular}

Setelah dibuat larutan dengan perbandingan di atas, maka larutan tersebut diaduk hingga campuran menjadi homogen, selanjutnya larutan dijemur di bawah sinar matahari yang cerah, setelah 5 menit diambil hasil sintesis nanopartikel sebanyak $\pm 3 \mathrm{~mL}$ 
untuk masing-masing perbandingan, dan dimasukan kedalam botol vial kemudian diamati perubahan warna dan diukur dengan spektrofotometer UV-Vis dengan spektrum absorbansi diamati pada panjang gelombang 280-700 nm.

Selanjutnya dilakukan pengamatan untuk lama waktu penjemuran 5 menit, 15 menit, 30 menit, 45 menit, 60 menit setelah pemanasan, kemudian sampel diletakan di dalam ruangan lalu diamati.

Untuk lama penjemuran 2 jam, 3 jam, 24 jam, 2 hari dan 7 hari memiliki perlakuan yang berbeda, yaitu dengan cara larutannya dijemur pada matahari langsung selama 1 jam kemudian dibiarkan di dalam ruang tertutup sampai tiba waktu 2 jam, 3 jam, 24 jam, 2 hari dan 7 hari. Hasil biosintesis NPP yang paling baik dari beberapa variasi akan digunakan untuk analisis lebih lanjut.

Untuk uji selektivitas digunakan 15 jenis logam. Logam-logam dibuat dengan cara melarutkan garam logamnya, untuk mendapatkan ion $\mathrm{Al}^{3+}, \mathrm{Ca}^{2+}$, $\mathrm{Cr}^{3+}, \mathrm{Co}^{2+}, \mathrm{Cu}^{2+}, \mathrm{Fe}^{2+}, \mathrm{Fe}^{3+}, \mathrm{Hg}^{2+}, \mathrm{K}^{+}, \mathrm{Mg}^{2+}, \mathrm{Mn}^{2+}, \mathrm{Na}^{+}$, $\mathrm{Ni}^{2+}, \mathrm{Pb}^{2+}$ dan $\mathrm{Zn}^{2+}$. Massa logam untuk pembuatan 250 ppm larutan standar dapat dapat dilihat pada Tabel 2 di bawah ini.

Tabel 2. Massa Garam logam untuk pembuatan larutan baku logam $250 \mathrm{ppm}$

\begin{tabular}{ll}
\hline \multicolumn{1}{c}{ Logam } & Massa $(\mathrm{mg})$ \\
\hline $\mathrm{Al}\left(\mathrm{NO}_{3}\right)_{3} \cdot 9 \mathrm{H}_{2} \mathrm{O}$ & 228,7 \\
$\mathrm{CaCl}_{2}$ & 68,7 \\
$\mathrm{Co}\left(\mathrm{NO}_{3}\right)_{2} \cdot 6 \mathrm{H}_{2} \mathrm{O}$ & 123,3 \\
$\mathrm{Cr}\left(\mathrm{NO}_{3}\right)_{3} \cdot 9 \mathrm{H}_{2} \mathrm{O}$ & 192,3 \\
$\mathrm{CuSO}_{4} \cdot 5 \mathrm{H}_{2} \mathrm{O}$ & 94,6 \\
$\mathrm{FeCl}_{2} \cdot 4 \mathrm{H}_{2} \mathrm{O}$ & 88,4 \\
$\mathrm{FeCl}_{3} \cdot 6 \mathrm{H}_{2} \mathrm{O}$ & 120,1 \\
$\mathrm{HgCl}_{2}$ & 33,7 \\
$\mathrm{KCl}$ & 47,4 \\
$\mathrm{MgCl}_{2} \cdot 6 \mathrm{H}_{2} \mathrm{O}$ & 210,4 \\
$\mathrm{MnSO}_{4} \cdot \mathrm{H}_{2} \mathrm{O}$ & 76,8 \\
$\mathrm{NaCl}$ & 63 \\
$\mathrm{NiSO}_{4} \cdot 6 \mathrm{H}_{2} \mathrm{O}$ & 111,4 \\
$\mathrm{PbNO}_{3}$ & 32,5 \\
$\mathrm{ZnCl}_{2}$ & 51,9 \\
\hline
\end{tabular}

Garam logam dengan massa seperti diatas ditimbang, kemudian dimasukkan pada labu ukur 100 $\mathrm{mL}$ dan ditambah aquabides sampai tanda batas.

Uji selektivitas NPP dilakukan dengan memasukkan $2 \mathrm{~mL}$ NPP pada kondisi optimum ke dalam masing-masing botol vial, selanjutnya ditambahkan 1 $\mathrm{mL}$ dari setiap logam standar dengan konsentrasi 250 ppm atau konsentrasi logam yang ada 83,33 ppm, diamati perubahan warnanya dan diukur absorbansinya. Selektivitas NPP ditentukan dengan mengetahui perubahan warna paling mencolok dan perubahan absorbansi paling besar pada masing-masing penambahan logam.

Uji sensitifitas dilakukan pada logam yang selektif terhadap NPP yang telah dibuat, dilakukan dengan mencampurkan NPP larutan dengan logam yang konsentrasinya divariasikan. NPP yang telah dibuat dimasukkan ke dalam botol vial sesuai variasi konsentrasi logam sebanyak $2 \mathrm{~mL}$ kemudian tambahkan logam dengan konsentrasi 250, 200, 150, $100,80,60$, $40,20,1 \mathrm{ppm}$, dan $800,600,400,200,100,40$, 20,10 terakhir 2 ppb masing-masing $1 \mathrm{ml}$. Diamati perubahan warna yang terjadi pada NPP serta diukur spektrum absorbansi dengan spektrofotometer UV-Vis pada panjang gelombang $280-700 \mathrm{~nm}$.

Penentuan kadar logam $\mathrm{Hg}$ secara spektrofotometei UV-Vis dilakukan dengan cara mengukur absorbansi sampel pada panjang gelombang optimum dari NPP. Larutan standar yang digunakan adalah NPP yang ditambahkan dengan $\mathrm{Hg} 2+$ berbagai konsentrasi ppm dan ppb, sedangkan pengukuran sampel dilakukan dengan preparasi terlebih dahulu. Sampel di preparasi dengan penambahan $\mathrm{NaOH} 2 \mathrm{M}$, ini dilakukan untuk mengendapkan logam $\mathrm{Fe}$ karena logam $\mathrm{Fe}$ mengganggu deteksi logam $\mathrm{Hg} 2+$. Sampel yang telah ditambahkan $\mathrm{NaOH} 2 \mathrm{M}$ lalu disaring dan filtratnya ditambahkan dengan $\mathrm{HCl} 2 \mathrm{M}$ untuk mengembalikan pH sampel pada kondisi semula

\section{HASIL DAN PEMBAHASAN}

NPP dibuat dengan mencampurkan larutan $\mathrm{AgNO}_{3}$ sebagai prekursor dengan ektrak buah $P$. flavicarva sebagai agen pereduksi $\mathrm{Ag}^{+}$menjadi $\mathrm{Ag}^{0}$ atau NPP kemudian dijemur pada sinar matahari untuk mempercepat reaksi pembentukan NPP.

Cahaya matahari akan memberikan energi yang diperlukan untuk reaksi pembentukan NPP, yang ditandai dengan adanya perubahan warna dari bening menjadi kuning hingga kuning kecoklatan, serta adanya puncak serapan pada panjang gelombang 400$500 \mathrm{~nm}$ pada pengukuran menggunakan spektrosfotometer UV-Vis yang merupakan nilai SPR (Surface Plasmon Resonances) dari NPP .

Untuk mendapatkan hasil NPP yang paling baik, maka diuji coba perbandingan volume filtrat air rebusan buah Passiflora flavicarva dengan prekursor perak dengan berbagai macam perbandingan sebagai berikut : 2:1, 1:1, 1:2 dan 1:3 (v/v). Hasil NPP diamati, difoto dan diukur dengan spektrofotometer UV-Vis pada waktu 5 menit, 15 menit, 30 menit, 45 menit, 60 menit, 2 jam, 3 jam, 24 jam, 2 hari dan 7 hari. Gambar perubahan warna NPP pada berbagai perbandingan volume ekstrak dan prekursor perak yang berbeda serta variasi waktu dapat dilihat pada Gambar 1. 


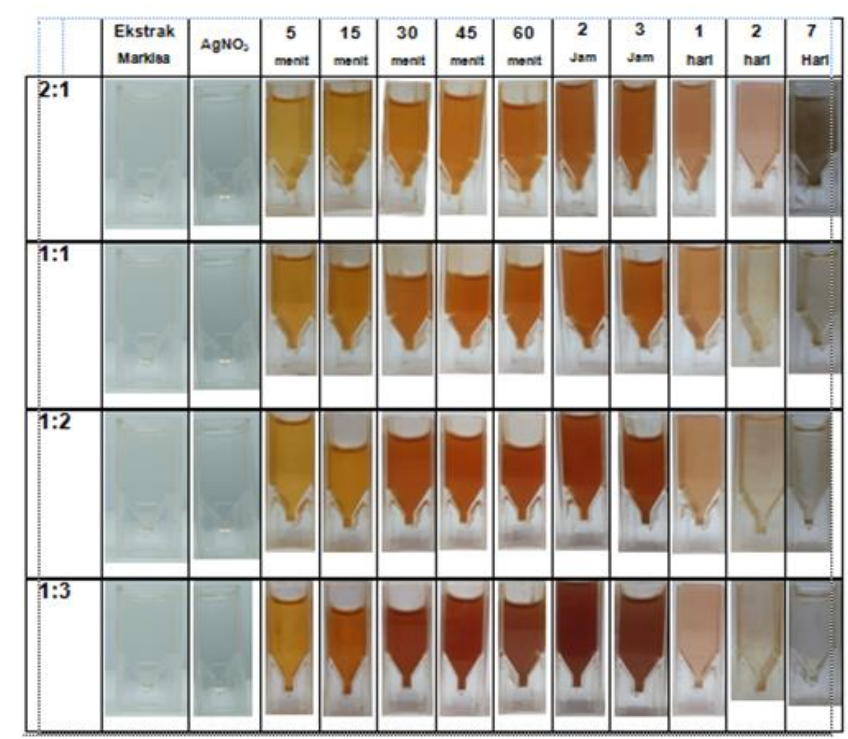

Gambar 1. Perubahan warna NPP terhadap variasi volume ekstrak P.flavicarva dengan $\mathrm{AgNO}_{3}$ dan waktu reaksi.

Untuk setiap perbandingan yang diuji coba pada waktu 5 menit sudah menghasilkan warna kuning kecoklatan yang artinya sudah mulai terbentuk NPP (Gambar 1), Warna NPP yang dihasilkan semakin pekat seiring dengan bertambahnya waktu reaksi sampai dengan 3 jam. Hal ini menandakan bahwa NPP yang terbentuk semakin banyak, namun warna larutan berubah menjadi lebih pudar atau bening ketika sudah mencapai waktu reaksi 1-7 hari. Hal ini terjadi akibat dari terjadinya agregat pada partikel nano yang ditandai dengan adanya endapan pada dasar botol. Agregat ini terjadi karena NPP ini sudah tidak stabil lagi sehingga NPP akan bergabung dan menghasilkan partikel tidak dalam bentuk nano lagi. Spektrum serapan UV-Vis dari NPP pada berbagai variasi volume ekstrak dengan $\mathrm{AgNO}_{3}$ dan waktu reaksi dapat dilihat pada Gambar 2a, 2b, 2c dan 2d di bawah ini .

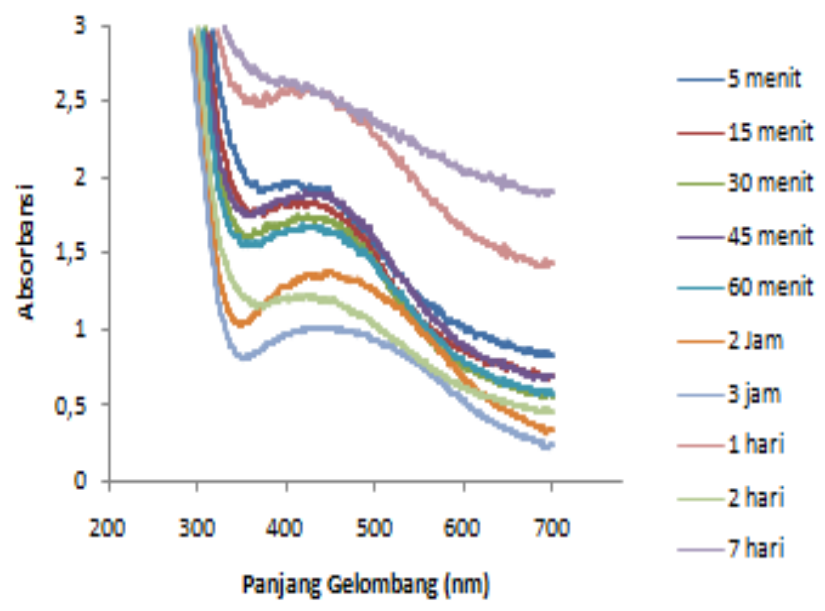

Gambar 2a. Spektrum serapan spektrofotometri UV-Vis hasil sintesis NPP pada perbandingan volume filtrat air rebusan buah P.flavicarva dengan $\mathrm{AgNO}_{3}(2: 1)$

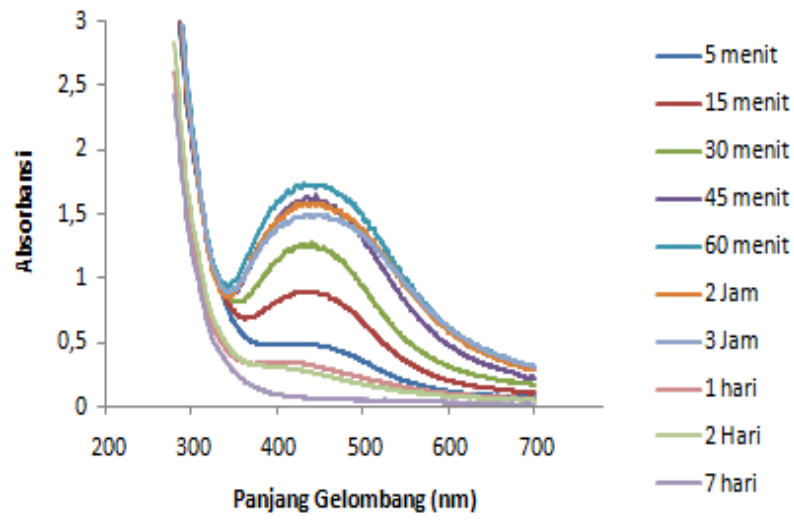

Gambar 2b. Spektrum serapan spektrofotometri UV-Vis hasil sintesis NPP pada perbandingan volume filtrat air rebusan buah $P$.flavicarva dengan $\mathrm{AgNO}_{3}(1: 1)$

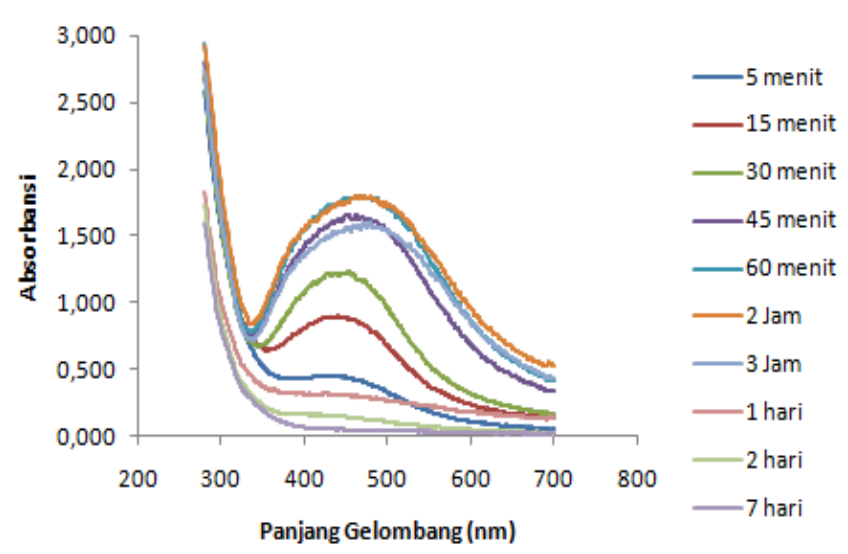

Gambar 2c. Spektrum serapan spektrofotometri UV-Vis hasil sintesis NPP pada perbandingan volume filtrat air rebusan buah P.flavicarva markisa dengan $\mathrm{AgNO}_{3}(1: 2)$

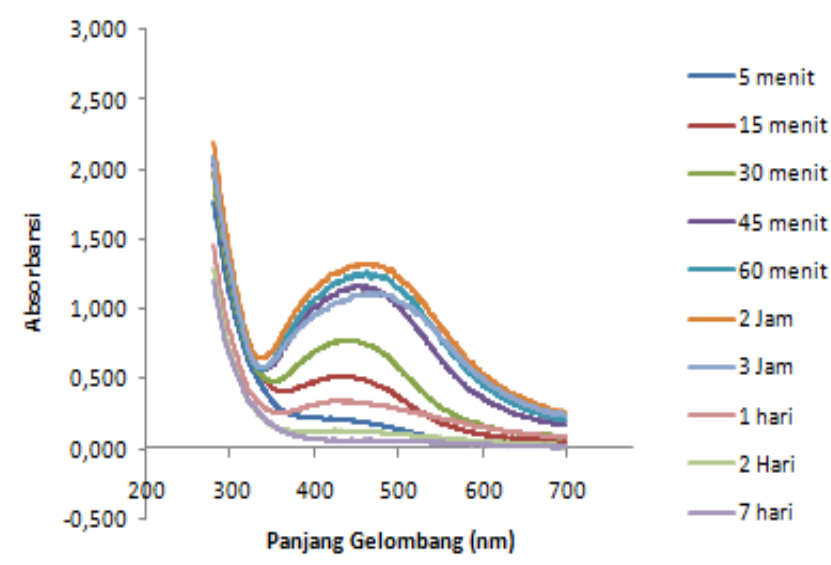

Gambar 2d. Spektrum serapan spektrofotometri UV-Vis hasil sintesis NPP pada perbandingan volume filtrat air rebusan buah P.flavicarva dengan $\mathrm{AgNO}_{3}(1: 3)$

Dari gambar di atas terlihat bahwa NPP yang dihasilkan paling optimal ditandai dengan absorbansi paling besar pada panjang gelombang 400-500 $\mathrm{nm}$ dengan puncak tunggal yang mengerucut. Dari Gambar 2 c dapat diketahui bahwa pada perbandingan 1:2 adalah perbandingan yang paling optimal karena pada perban- 
dingan ini puncak yang dihasilkan mengerucut dengan absorbansi paling besar. Pada perbandingan 1:2 ini waktu yang optimum untuk membentuk NPP adalah pada waktu 2 jam dengan absorbansi 1,803 pada panjang gelombang $461 \mathrm{~nm}$.

Dari penjelasan di atas maka dapat disimpulkan bahwa untuk mendapatkan NPP yang paling optimum dapat dibuat dengan menambahkan $\mathrm{AgNO}_{3}$ yang lebih banyak dari pada ekstrak buah $P$. flavicarva dengan perbandingan 1:2 dan waktu reaksi 2 jam, setelah didapatkan kondisi optimal maka dapat dilanjutkan dengan uji selektivitas.

Pengujian selektivitas logam ini dilakukan terhadap masing-masing logam yang diuji dalam konsentrasi $250 \mathrm{ppm}$, ditambahkan kedalam NPP volume (1:2). Hasil uji keselektivitas NPP terhadap berbagai logam dapat dilihat pada Gambar 3.

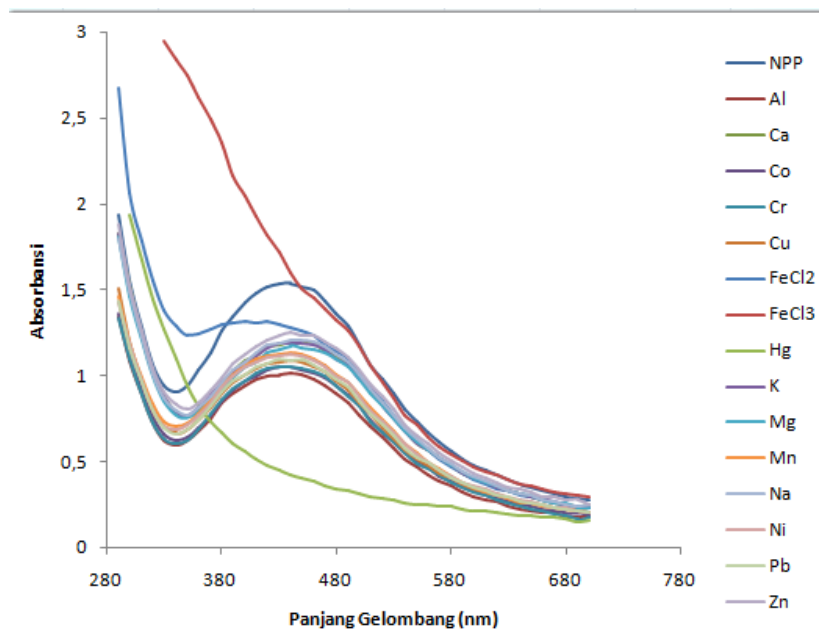

Gambar 3. Spektrum serapan spektrofotometer UV-Vis dari NPP akibat penambahan berbagai logam dengan konsentrasi $250 \mathrm{ppm}$

Dari Gambar 3. terlihat bahwa spektrum serapan yang dihasilkan oleh NPP yang mengalami perubahan puncak absorbansi yang paling besar terjadi ketika ditambahkan ion logam $\mathrm{Hg}^{2+}$ dan $\mathrm{Fe}^{3+}$ karena dua logam ini tidak lagi memiliki puncak absorbansi. Hilangnya puncak absorbansi ini dikarenakan terjadinya reaksi antara logam tersebut dengan NPP. Perubahan puncak absorbansi dari NPP akibat penambahan ion logam $\mathrm{Hg}^{2+}$ lebih besar dari logam $\mathrm{Fe}^{3+}$ ini bisa dilihat dari nilai absorbansi pada panjang gelombang $461 \mathrm{~nm}$ yang dihasilkan pada waktu penambahan ion $\mathrm{Hg}^{2+}$ dan $\mathrm{Fe}^{3+}$, untuk logam $\mathrm{Hg}^{2+}$ absorbansinya turun dengan besar perubahannya 1,108 sedangkan logam $\mathrm{Fe}^{3+}$ absorbansinya turun dengan besar perubahan 0,05. Akibat perubahan absorbansi yang lebih besar pada logam $\mathrm{Hg}^{2+}$ ini maka dapat disimpulkan NPP yang terbentuk hanya selektif terhadap logam $\mathrm{Hg}^{2+}$

NPP selektif terhadap logam $\mathrm{Hg}^{2+}$ diakibatkan proses oksidasi yang dilakukan $\mathrm{Hg}^{2+}$ pada NPP akibatnya $\mathrm{Ag}^{0}$ pada NPP berubah menjadi $\mathrm{Ag}^{+}$. Proses oksidasi ini diakibatkan oleh nilai potensial reduksi dari $\mathrm{Hg}^{2+}$ yang lebih besar dari $\mathrm{Ag}^{2+}$ yaitu $\mathrm{Hg}^{2+}$ sebesar $+0,92 \mathrm{~V}$ sedangkan $\mathrm{Ag}^{+}$sebesar $+0,80$.

Persamaan setengah reaksi redoksnya yang terjadi anatara logam $\mathrm{Ag}+$ dengan $\mathrm{Hg} 2+$ adalah sebagai berikut:

$$
\begin{array}{cl}
\qquad \mathrm{Hg}^{2+}+2 \mathrm{e}^{-} \longrightarrow \mathrm{Hg}_{2}{ }^{2+} & \mathrm{E}^{0}=+0.92 \mathrm{~V} \\
\mathrm{Ag}^{+}+\mathrm{e}^{-} \longrightarrow \mathrm{Ag} & \mathrm{E}^{0}=+0.80 \mathrm{~V} \\
\text { Anoda (Oksidasi): } 2 \mathrm{Hg}^{2+}+2 \mathrm{e}^{-} \longrightarrow \mathrm{Hg}_{2}^{2+} & \mathrm{E}^{0}=+0.92 \mathrm{~V} \\
\text { Katoda (Reduksi): } \mathrm{Ag} \longrightarrow \mathrm{Ag}^{+}+\mathrm{e}^{-} & \mathrm{E}^{0}=-0.80 \mathrm{~V} \mathrm{x} 2 \\
\hline \mathrm{Hg}_{2}{ }^{2+}+\mathrm{Ag}^{+} & \mathrm{E}^{0} \text { sel }=+0,12 \mathrm{~V}
\end{array}
$$

Dari penjelsan diatas maka dapat sisimpulkn bahwa NPP yang terbentuk selektif terhadap logam $\mathrm{Hg}^{2+}$, oleh karena itu maka dapat diuji sensitivitas lebih lanjut terhadap logam tersebut.

Uji sensitivitas dilakukan untuk mengetahui konsentrasi minimum dari logam $\mathrm{Hg}^{2+}$ yang dapat dideteksi oleh NPP, menggunakan metode spektrofotometri UV-Vis.. Kurva kalibrasi yang dihasilkan dapat dilihat pada Gambar 4.

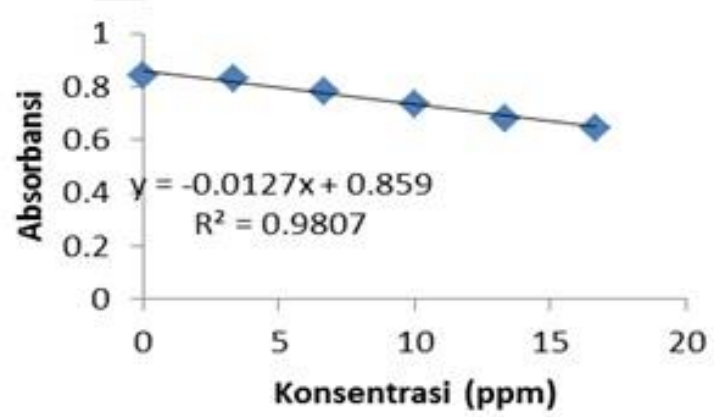

Gambar 4. Kurva kalibrasi NPP + logam Hg dalam konsentrasi ppm dengan spektrofotometer UV-Vis

Pada Gambar 5. dapat diamati perubahan spektrum absorbansi akibat penambahan logam $\mathrm{Hg}^{2+}$.

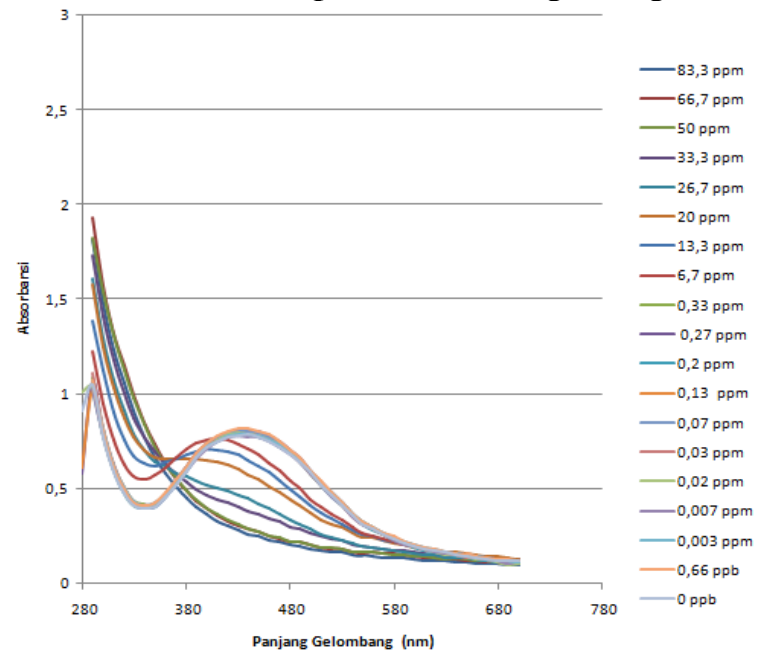

Gambar 5. Spektrum serapan NPP akibat penambahan logam $\mathrm{Hg}^{2+}$ berbagi konsentrasi 
Spektrum serapan yang dihasilkan oleh NPP akibat penambahan konsentrasi logam $\mathrm{Hg}^{2+}$, ketika konsentrasi $\mathrm{Hg}^{2+}$ bertambahnya maka semakin menurun spektrum yang dihasilkan (Gambar 5). Hal ini terjadi karena proses oksidasi yang semakin bertambah pada NPP seiring dengan bertambahnya konsentrasi. Konsentrasi yang sensitif dengan spektrofotometer UV-Vis adalah 6,7 ppm, hal ini bisa dilihat dari masih bergesernya puncak absorbansi dan pola serapan jika dibandingkan dengan blanko.

\section{KESIMPULAN}

Ekstrak buah $P$. flavicarva (markisa) dapat digunakan untuk biosintesis NPP dengan bantuan sinar matahari. NPP yang disintesis selektif terhadap logam merkuri sampai dengan konsentrasi 6,7 ppm. Dari hasil penelitian ini maka disimpulkan bahwa NPP yang terbentuk dapat digunakan untuk mendeteksi logam merkuri dengan konsentrasi terendah hingga 6,7 ppm.

\section{DAFTAR PUSTAKA}

[1] Achmad, H. 1992. Kimia Unsur dan Radiokimia. Bandung: PT. Citra Aditya Bakti.

[2] Saputra, A., Prasetio, A. B., Radiarta, I. N. 2010. Distribusi Logam Berat dalam Air dan Sendimen di Perairan Danau Maninjau, Provinsi Sumatra Barat. Prosiding Forum Inovasi Tekno-logi Akuakultur 2010. Pusat Riset Perikanan Budidaya. http://repository.ipb.ac.id

[3] Wijana, N. 2014. Biologi dan Lingkungan. Plantaxia. Yogyakarta.

[4] Handayani, W. 2011. Pemanfaatan Tanaman Tropis Untuk Biosintesis Nanopartikel Perak dan Aplikasinya Sebagai Indicator Kolorimetri Keberadaan Logam Berat. Tesis. FMIPA Universitas Indonesia Jakarta. http://lontar.ui.ac.id.

[5] Ariyanta, H. A., Wahyuni, S., Priatmoko, S. 2014. Preparasi Nanopartikel Perak dengan Metode Reduksi dan Aplikasinya Sebagai Antibakteri Penyebab Infeksi. Jurnal. Indo. Journal Chemistry Science. ISSN 2252-6951. http://journal. unnes. ac.id.

[6] Lembang, Y E. 2013. Sintesis Nanopartikel Perak dengan Metode Reduksi Menggunakan Bioreduktor Ekstrak Daun Ketapang (Terminalia catappa). Jurusan Kimia MIPA Universitas Hasanudin, Makasar.
[7] Liu, J., Jiang, G. 2015. Silver Nanoparticles in the Enviroment. Springer. ISBN 978-3-66246070-2. http://www.springer.com

[8] Masakke, Y; Sulfikar; Rasyid, M. 2015. Biosynthesis of Silver Nanoparticles using Methanol Extract of Mangosteen Leaves (Garcinia Mangostana L.). Jurnal Sains Mat, 4(29). ISSN 2086-6755. http://ojs.unm.ac.id.

[9] Sathiskumar, M., Snecha,K., Won, S. -W., Cho, C. W., Kim, S., Yun, Y. S., 2009, Cinnamon zeylanicum Bark Exract and Powder Mediated Green Synthesis of Nano crystalline Silver Particles and Its Bactericidal Activity. Journal of Colloids and Surfaces B: Biointerfaces, 73(2009): 332-338.

[10] Firdaus ML, Fitriani I, Wyantuti S, Hartati YW, Khaydarov R, McAlister JA, Obata H, Gamo T.. 2017. Colorimetric Detection of Mercury (II) Ion in Aqueous Solution Using Silver Nanoparticles. Analyt. Sci, 33,800.

[11] Karsinah, S, FH; Mansyur, A. 2010. Markisa Asam (Passiflora edulis Sims) Buah Eksotik Kaya Manfaat. IPTEK Hortikultura. http://hortikultura.litbang.pertanian.go.id

[12] Annadhasan,M; Kasturi, J; Rajendiran, N . 2015. Green synthesis of gold nanoparticles under sunlight irradiation and their colorimetric detection of $\mathrm{Hg} 2+$ and $\mathrm{Co}^{2+}$ ions. The Royal Society of Chemistry. http://pubs.rsc.org.

[13] Firdaus, M.L, Andriana, S, Elvinawati, Alwi, W, Swistoro, E, A Ruyani and Sundaryono,A. . 2017. Green Synthesis of Silver Nanoparticles Using Carica papaya Friut Extract Under Sunlight Irradiation and Their Colorimetric Detection of Mercury Ions, J. Phys: Conf. Ser., 817,012029 .

Penulisan Sitasi Artikel ini ialah :

Maryani,D, Firdaus,M.L, Nurhamidah. 2017, Biosintesis Nanopartikel Perak Menggunakan Ekstrak Buah Passiflora flavicarva (Markisa) Untuk Mendeteksi Logam Berat, Alotrop, 1(1): 49-54. 